\title{
KOMPARÁCIA POŠTOVÝCH SCHRÁNOK VYUŽÍVANÝCH POŠTOVÝMI OPERÁTORMI POSKYTUJÚCIMI UNIVERZÁLNU SLUŽBU VO VYBRANÝCH KRAJINÁCH
}

\author{
Dominika Koncová 1 , Iveta Kremeňová ${ }^{2}$
}

\begin{abstract}
The issue of Paper is the first mile, specifically, collecting mail via letterboxes, by postal operators providing universal services, and necessary implementation of innovations in them. In recent years, there was downward tendency of sent mail, so the question arises as to whether it is necessary to collect mail from letterboxes that have not been filled or if to omit letterboxes altogether.
\end{abstract}

Keywords: Letterbox, parcel box, automated parcel locker

\section{Úvod}

Podnikanie na poštovom trhu je značne ovplyvňované legislatívou, očakávaniami a požiadavkami zákazníkov ako aj konkurenciou samotných poštových podnikov. Ked’že ciel'om podnikov je získat' konkurenčnú výhodu na trhu a maximalizovat' svoj zisk, podniky sa snažia nájst' miesta, kde by bolo možné znížit' náklady, či už náklady prevádzkové, mzdové alebo iné.

Konkurenčnú výhodu je však možné získat' aj implementovaním inovácií, ktoré ostatné podniky na trhu nepoužívajú alebo ich aplikovali v obmedzenej podobe. Inovovanie môže nastat' $v$ rôznych oblastiach podnikania, či už sa jedná o inovácie $v$ oblasti IKT (informačno-komunikačných technológií), implementovania ekologických opatrení pre zníženie dopadu na životné prostredie z podnikatel'skej činnosti, sledovanie nových trendov v prístupe $\mathrm{k}$ zákazníkom $\mathrm{z}$ hl'adiska marketingu a personalistiky, či vytvárania nových prístupových bodov na komunikáciu s podnikom. Ergonomické riešenia využívané podnikmi doteraz, môžu byt' zastaralé a neekonomické pre budúcnost'. Podnikanie ako také musí hl'adat' nové riešenia a optimalizovat' svoje procesy a postupy, či už aj samotné technológie.

\section{Analýza súčasného stavu vo vybraných krajinách}

Poštové schránky sú ako kontaktné miesto na podaj resp. dodaj zásielok používané poštovými podnikmi $\mathrm{v}$ rozličných podobách. Niektoré podniky využívajú balíkomaty na podávanie a aj dodávanie zásielok, iné podniky využívajú samoobslužné kiosky na prípravu a podaj zásielok. Ďalšie spoločnosti využívajú poštové schránky iba na podaj listových zásielok, len na dodanie listových, prípadne listových a balíkových zásielok a pod. Pre niektoré podniky $\mathrm{v}$ niektorých štátoch je inováciou zavedenie balíkomatov, pre iné poštové podniky je takéto kontaktné miesto považované za zastaralé a v rámci Industry 4.0 myslia

\footnotetext{
${ }^{1}$ Ing. Dominika Koncová, Katedra spojov, FPEDAS, Žilinská univerzita v Žiline,

e-mail: dominika.koncova@stud.uniza.sk

${ }^{2}$ doc. Ing. Iveta Kremeňová, PhD., Katedra spojov, FPEDAS, Žilinská univerzita v Žiline,

e-mail: iveta.kremenova@fpedas.uniza.sk
} 
revolučne a investujú svoje finančné prostriedky do robotizácie a na vývoj autonómnych vozidiel, či dronov určených na vyzdvihnutie alebo doručenie zásielky. Zjednodušene je možné povedat', že $v$ jednotlivých štátoch je možné pozorovat' rôzny stupeň digitalizácie a autonómnosti podaja, príp. dodania zásielok takouto formou kontaktného miesta.

Vhodným príkladom zariadenia na podaj zásielok je samoobslužný kiosk pošty Royal Mail, rakúska SB zóna (samoobslužná zóna) a samoobslužný kiosk Americkej pošty (USPSpoštová služba Spojených štátov). Kým SB zóna je kontaktné miesto, v ktorom má zákazník možnost' pripravenia zásielky vrátane používania obalových materiálov, samoobslužný kiosk USPS a kiosk od Royal Mail touto možnost'ou nedisponuje. Zákazník teda môže považovat' využívanie SB zóny za výhodnejšie, ked'že zásielku nemusí mat' predpripravenú a potrebuje mat' pri sebe len obsah zásielky a adresné údaje, lebo zvyšok činností spojených s prípravou zásielky je schopný vykonat' na mieste. Na porovnanie, na Slovensku je možné využit' na podávanie listových zásielok poštové schránky. V nich však nie je zákazníkovi umožnené si zásielku zabalit', odvážit', resp. nemôže vyplácat' za jej podanie rôznymi spôsobmi, ako je úhrada kreditnou kartou, či hotovost'ou. Zásielka v tomto prípade musí byt' označená poštovými známkami v príslušnej hodnote, resp. môže byt' zat’ažená doplatným, pričom jej môže byt' znížená kvalitatívna trieda dodania. [1, 2, 3, 4]

Kým na Slovensku sa len pred pár rokmi začali implementovat' a využívat' balíkomaty na plno, $v$ zahraničí je to už pomerne známa a využívaná technológia. Príkladom zahraničného využitia takéhoto typu balíkomatu je Inteligentný terminál Ray s pohonom od spoločnosti Welltec, ktorý okrem d’alších služieb ako sú platba daní, správa automobilov, leštenie topánok, práčovne a pod., zabezpečuje prvú a poslednú míl'u pre zákazníka, teda umožňuje podaj listových a registrovaných listových zásielok ako aj dodanie balíkových zásielok. Toto zariadenie je schopné identifikovat' parametre zásielky, ktorými sú rozmery a váha, prípadne objem. Dalej je terminál schopný označit' smerové znaky ako aj spracovat' viaceré listové zásielky. Podstatnou súčast'ou je aj tlačenie účteniek. Za poskytnutie služby je možné platit' hotovost'ou, kreditnými kartami, RFID (rádiofrekvenčný identifikačný tag) a NFC (komunikácia prebiehajúca $\mathrm{v}$ poli $\mathrm{s}$ krátkym dosahom) technológiou pre dodatočné platby. Zariadenie tiež disponuje dvoma skenermi na načítanie informácií o účtoch za energie a na platbu daní. $[5,6,7]$

Ďalej sa článok bude venovat’ poštovým schránkam poskytovatel'ov univerzálnej služby vo vybraných krajinách.

\section{Alokácia poštových schránok vo vybraných krajinách}

Jednotlivé štáty majú rôznu legislatívnu úpravu, čo sa týka počtu ako aj formy poštových schránok u poskytovatel'ov univerzálnej služby. Pre štáty ako je Česko a Slovensko je dôležitá hustota zal'udnenia jednotlivých sídelných celkov, prípadne vzdialenost' od najbližšej poštovej schránky $\mathrm{v}$ obciach so stanoveným počtom obyvatel'ov. Pol'sko má upravenú špecifikáciu pokrytia územia poštovými schránkami obmedzenú dostupnost'ou pre zdravotne hendikepované osoby, pričom pokrytie poštovej siete poštovým podnikom nesmie byt' menšie ako 95\%. [8]

\section{Slovensko}

Pre Slovenskú republiku, konkrétne pre poskytovatel'a univerzálnej služby Slovenskú poštu, a. s. (d’alej len Slovenská pošta), sú v oblasti alokovania poštových schránok záväzné najmä dokument Požiadavky na kvalitu univerzálnej služby a Zákon o poštových službách a o zmene a doplnení niektorých zákonov č. 324/2011 Z. z. [9, 10] 
Na území Slovenska kontroluje dodržiavanie zákonných podmienok týkajúcich sa univerzálnej poštovej služby Úrad pre reguláciu elektronických komunikácií a poštových služieb. Samoobslužné zariadenia, určené na podaj alebo dodaj zásielok pri poskytovatel'ovi univerzálnej služby, sú v slovenských podmienkach rozdelené nasledovne:

- určené na podávanie zásielok: poštová schránka;

- určené na podávanie a dodávanie zásielok: P.O.Box, Balíkomat;

- určené na dodávanie poštových zásielok: Post Box, OutBox.

P.O.Box je $\mathrm{v}$ budove pošty ( $\mathrm{v}$ priestoroch určených pre verejnost') situovaný samostatný priečinok, ktorý sa využíva na dodávanie aj podávanie zásielok. Je uzamykatel'ný. Post Box je $\mathrm{v}$ prevádzkových priestoroch pošty alokovaný priečinok, ktorý sa využíva na dodávanie zásielok (tieto sa poskytujú zákazníkom v prípade, že Slovenská pošta už nedisponuje vol'nými P.O.Boxmi). OutBox je zariadenie podobné Post Boxu. Rozdiel medzi nimi je v ich umiestňovaní. OutBoxy sú situované mimo budovu pošty, taktiež sa jedná o uzamykatel'ný samoobslužný priečinok. OutBox je poskytovaný pre adresátov, ktorým nie je možné z nejakého dôvodu poskytnút' na konkrétnom mieste doručovaciu službu, pričom sa využíva na dodávanie zásielok. Balíkomaty sú rýchle a bezpečné zariadenia na posielanie a zber zásielok - balíkov 24/7, teda aj mimo bežných stránkových hodín. [8]

Článok bude následne orientovaný na komparáciu poštových schránok, určených na podaj zásielok listovej povahy.

Podl’a Zákona o poštových službách je v čl. I, prvej časti - základných ustanoveniach v $\S 3$ definovaná univerzálna služba ako: „ponuka poštových služieb podl’a odseku 2, ktorá slúži na zabezpečenie minimálneho uspokojenia potrieb všetkých uživatelov poštových služieb na územi Slovenskej republiky tak, aby bola zabezpečená dostupnost' pristupových miest verejnej poštovej siete a kontaktných miest verejnej poštovej siete, za rovnakých podmienok, $v$ ustanovenej kvalite, za primeranú cenu, každý pracovný den̆ najmenej s jedným vybraním a dodaním denne. Poskytovatel'om univerzálnej služby je jeden alebo viac poštových podnikov, ktorý je povinný poskytovat' univerzálnu službu na základe poštovej licencie a za podmienok a spôsobom podl'a tohto zákona." [10]

V Požiadavkách na kvalitu univerzálnej služby sú v článku 4, v bodoch 8 až 14 spísané presne definované požiadavky na rozmiestnenie a počet poštových schránok v danom sídelnom celku. Ďalej sú v dokumente určené zásady na zabezpečenie kvality univerzálnej služby a jej základné charakteristiky s požadovanými normami kvality v rozsahu dostupnosti miestnej a časovej pre univerzálnu službu, sledovania času prepravy a bezpečnosti zásielok, informácií o univerzálnej službe, vybavovania st’ažností vrátane reklamácií a zist'ovania spokojnosti zákazníkov. [9]

Tieto podmienky stanovujú, že poštová schránka je zriadená $\mathrm{v}$ obci $\mathrm{s}$ počtom obyvatel'ov:

- 500 - 1000: ak je najbližšia poštová schránka alokovaná v obci vo vzdialenosti väčšej ako $5 \mathrm{~km}$;

- 1001 - 3000: je zriadená minimálne 1 poštová schránka;

- 3001 - 30000: je zriadená minimálne 1 poštová schránka na každých (aj začatých) 3000 obyvatel'ov;

- viac ako 30000: je zriadených poštových schránok minimálne 10 a na každých (aj začatých) 5000 obyvatel'ov (nad 30000) pripadá minimálne 1 poštová schránka. [9] 


\section{Česko}

Alokovanie poštových schránok je pre Českú republiku definované v „Zákonu o poštovních službách a o změně některých zákonů (zákon o poštovních službách) č. 29/2000 Sb.” [11], kde je univerzálna služba chápaná pod názvom základná služba poštovej služby, pričom spíňa podmienky stanovené podobne ako na Slovensku. V pasáži: Čast' prvá, v hlave I- úvodné ustanovenia je v $\$ 3$ Základné služby, podl'a bodu 2 definované poskytovanie základnej služby:

- trvalo na celom území Českej republiky prostredníctvom siete prevádzok (ktorých minimálny počet stanoví na návrh Úradu vláda nariadením; do tohto počtu sa započítavajú aj prevádzky vedené tret'ou stranou menom a na účet držitel'a poštovej licencie);

- v stanovenej kvalite, ktorá je v súlade s potrebami verejnosti;

- za dostupné ceny umožňujúca využívanie základných služieb v rozsahu zodpovedajúcom bežnej potrebe osôb;

- každý pracovný deň a musí umožnit' v týchto dňoch najmenej 1 poštové podanie a d’alej aspoň 1 dodanie na adresu každej fyzickej alebo právnickej osoby, alebo vo výnimočných prípadoch, predovšetkým ak je miesto dodania nebezpečné alebo neprimerane t’ažko dostupné, ktoré sú stanovené vykonávacím právnym predpisom podl'a odstavca 3, jedno dodanie do vhodného zariadenia alebo dodávacej schránky;

- spôsobom, ktorý odpovedá požiadavkám úradného doručovania písomnosti podl'a zvláštneho právneho predpisu. [11]

Prakticky je však stanovený počet poštových schránok samostatne pre sídelné celky s počtom obyvatel'ov do 10000 a nad 10000 v určitom pomere. V Česku je poskytovatel'om univerzálnej služby Česká pošta, s. p. (d’alej len Česká pošta)

\section{Pol'sko}

Hustota rozmiestnenia poštových schránok je definovaná vo Vestníku zákonov Pol'skej republiky z roku 29. apríla 2013 o podmienkach poskytovania univerzálnych služieb určeným poštovým podnikom. Na základe článku 47 poštového zákona z 23 . novembra 2012 (Journal of Laws, položka 1529) a d'alej podl'a zákona č. 545 v kapitole 4, podl'a $\$ 26$ je definovaný:

- ako podiel (percentuálny) poštových schránok, ktoré musia byt’ umiestnené takým spôsobom a na takom mieste, ktorý ich použitie umožňuje zdravotne postihnutej osobe, používajúcej invalidný vozík. Týka sa to najmä poštových schránok inštalovaných na pobočkách určeného poštového podniku alebo v týmito pobočkami prevádzkovaných nehnutel'nostiach, ktorý nesmie byt' menší ako 95\% v celkovom počte poštových schránok nainštalovaných určeným poštovým podnikom v miestnej poštovej oblasti.

- počet poštových schránok odosielatel'a, by sa mal prispôsobit' potrebám miestnej komunity. Jedná sa o poštové schránky odosielatel'a, ktoré sú inštalované určeným poštovým podnikom v miestnej poštovej oblasti a ktoré sú umiestnené spôsobom uvedeným v predošlom odseku. [8, 12]

V Pol'sku je poskytovatel'om univerzálnej služby Poczta Polska, s. a. (d’alej ako Pol’ská pošta). 


\section{Spojené král'ovstvo Vel'kej Británie a Severného Î́rska}

Poskytovanie poštových služieb v Spojenom král'ovstve zabezpečuje Royal Mail. Je to poštový operátor, ktorý poskytuje aj univerzálnu službu. Zákon o poštových službách Vel'kej Británie z roku 2011 uvádza, okrem iného, aj minimálnu požiadavku na univerzálnu službu v časti 3, pod sekciou číslo 31. [13]

Minimálne požiadavky dostupnosti, miestnej a časovej, v rámci univerzálnej služby v tejto krajine sú:

- „Aspoň jedno zbieranie (zbieranie zabezpečené prostredníctvom poštových kurzov tzv. „zberné jazdy“ alebo poštových doručovatelov) listových zásielok sobotu z každého prístupového bodu v Spojenom král'ovstve použivaného na účely vyberania poštových balikov alebo akýchkol'vek ich typov, určeného na d'alši prenos $v$ súvislosti $s$ poskytovaním univerzálnej poštovej služby.

- Aspoň jedno zbieranie iných poštových balikov vykonávaný každý pondelok - piatok zo všetkých prístupových bodov v Spojenom král'ovstve použivaných na tento účel.

- Služba prepravy poštových balíkov z jedného miesta na iné poštou (zahrňujúca služby ich náhodného vyberania, zbierania, triedenia a doručovania) za prijatelné ceny podmienené $v$ súlade s verejnou tarifou, ktorá je uniformná v celom Spojenom královstve." [8]

\section{Ciel' a metodológia}

Jednotliví poštoví operátori podliehajú iným legislatívnym úpravám, ked’že poskytujú svoje služby v rôznych štátoch. Hlavným ciel'om článku je komparácia vybraných poštových podnikov, poskytujúcich univerzálnu službu, z hl'adiska využivania poštových schránok, určených na podaj listových zásielok a poukázat' na zastaranost' niektorých typov takýchto schránok. Informačnými zdrojmi sú zákonné požiadavky vybraných štátov, dokument Požiadavky na kvalitu univerzálnej služby, interné materiály Slovenskej pošty, audiovizuálne materiály a vedecké práce. V článku sme použili najmä metódu analýzy, komparácie a dedukcie. V rámci analýzy bolo požité excerpovanie údajov na zber informácií z použitej literatúry. Selektovanie bolo použité na triedenie získaných informácií a komparácia bola využitá na porovnanie jednotlivých legislatívnych požiadaviek. V závere bol použitý proces odvodzovania - dedukcia.

\section{Výsledky analýzy}

Porovnatel'né podmienky, čo sa týka počtu a lokalizovania poštových schránok sú v štátoch Česko a Slovensko. Preto je analýza zameraná na tieto dva štáty. V článku je uvedená aj komparácia Slovenska so Spojeným král'ovstvom, táto však zanedbáva rozličné podmienky alokovania poštových schránok.

V tabul'ke 1 sú uvedené počty poštových schránok a počet balíkomatov, za obdobie 2015-2018 v Českej a Slovenskej republike. 
Tabul'ka 1 Počet poštových schránok a balíkomatov v Česku a Slovensku v obdobiach 2015-2018

Zdroj: [8]

\begin{tabular}{|l|c|c|c|c|c|c|c|c|}
\hline Krajina & \multicolumn{3}{|c|}{ Slovenská republika } & \multicolumn{4}{c|}{ Česká republika } \\
\hline Obdobie & $\mathbf{2 0 1 5}$ & $\mathbf{2 0 1 6}$ & $\mathbf{2 0 1 7}$ & $\mathbf{2 0 1 8}$ & $\mathbf{2 0 1 5}$ & $\mathbf{2 0 1 6}$ & $\mathbf{2 0 1 7}$ & $\mathbf{2 0 1 8}$ \\
\hline $\begin{array}{l}\text { Počet poštových } \\
\text { schránok }\end{array}$ & 5570 & 4764 & 4756 & 4746 & 21698 & 21535 & 21303 & 21047 \\
\hline Počet balikomatov & - & - & 42 & 45 & 10 & - & 122 & 222 \\
\hline $\begin{array}{l}\text { Počty schránok a } \\
\text { balíkomatov spolu }\end{array}$ & 5570 & 4764 & 4798 & 4791 & 21708 & 21535 & 21425 & 21269 \\
\hline
\end{tabular}

Priemerný počet schránok na Slovensku za sledované obdobie je 4959 a v Česku je to 21396 schránok. Priemerné relatívne vyt’aženie schránok na obyvatel'a na Slovensku je 0,09\% a v Česku 0,20\% v období 2015-2018, čo predstavuje zat’aženie schránok na Slovensku približne o $45 \%$ väčšie ako v Česku. Počet obyvatel'ov prislúchajúcich na 1 poštovú schránku na Slovensku v období 2015-2018 je 0,02\%, teda 1105 obyvatel'ov z celkového počtu obyvatel'ov k decembru 2018. V Česku na 1 schránku pripadá 499 obyvatel'ov, teda $0,005 \%$ z celkového počtu obyvatel'ov k decembru 2018. Počet obyvatel'ov prislúchajúcich na jednu poštovú schránku je na Slovensku približne dvojnásobne väčší ako v Česku. Pri komparácií Slovenska a Spojeného král'ovstva je možné tvrdit' nasledovné. Priemerný počet poštových schránok na podaj listov v Spojenom král'ovstve, v období 2015-2018, je 115282. Priemerné relatívne vyt'aženie schránok na obyvatel'a v Spojenom král'ovstve je $0,172 \%$ v období 20152018. Počet obyvatel'ov prislúchajúcich na 1 poštovú schránku v Spojenom král'ovstve v období 2015-2018 je 0,005\%, teda 582 obyvatel'ov z celkového počtu obyvatel'ov k decembru 2018. Priemerné relatívne vyt’aženie schránok na obyvatel'a v Slovenskej republike predstavuje približne polovicu relatívneho vyt’aženia schránok v Spojenom královstve v sledovanom období. Počet obyvatel'ov prislúchajúcich na 1 poštovú schránku je na Slovensku približne štvornásobne väčší ako v Spojenom král'ovstve.

Česká pošta v roku 2019 znížila počty poštových schránok na 20699, k októbru 2020 už eviduje len 20025 poštových schránok. [14, 15] Na Slovensku k decembru 2019 fungovalo 60 BalíkoBoxov a podl'a plánov do konca roka 2020 plánuje Slovenská pošta prevádzkovanie spolu 135 BalíkoBoxov. [16] BalíkoBoxy od Slovenskej pošty sú orientované na balíkové zásielky, kým v zahraničí je bežný aj podaj/dodaj listových zásielok takýmito schránkami.

Na porovnanie s tabul'kou $1 \mathrm{v}$ tabul'ke 2 sú uvedené počty poštových schránok podl'a typu, a to poštové schránky zamerané na podaj listových zásielok a automatizované balíkové schránky v rokoch 2016-2018 podl'a databázy Svetovej poštovej únie (UPU), kde ND predstavuje nedefinovaný údaj, pomlčka predstavuje údaj, ktorý poštový operátor pre UPU nedodal a 0 znamená, že takýmito schránkami operátor nedisponuje.

Tabul'ka 2 Porovnávané krajiny podl’a uvedených kritérií v rokoch 2016-2018 zo štatistík UPU

Zdroj: [17]

\begin{tabular}{|c|c|c|c|c|}
\hline Krajina & Kritérium & 2016 & 2017 & 2018 \\
\hline \multirow{2}{*}{$\begin{array}{l}\text { Česká } \\
\text { republika }\end{array}$} & $\begin{array}{l}\text { Počet automatizovaných } \\
\text { balikových schránok }\end{array}$ & 0 & 0 & 0 \\
\hline & Počet schránok & 21535 & 21303 & 21047 \\
\hline \multirow{2}{*}{$\begin{array}{l}\text { Slovenská } \\
\text { republika }\end{array}$} & $\begin{array}{l}\text { Počet automatizovaných } \\
\text { balikových schránok }\end{array}$ & 22 & 45 & 45 \\
\hline & Počet schránok & 4764 & 4756 & 4746 \\
\hline \multirow{2}{*}{$\begin{array}{l}\text { Pol'ská } \\
\text { republika }\end{array}$} & $\begin{array}{l}\text { Počet automatizovaných } \\
\text { balikových schránok }\end{array}$ & 40 & ND & - \\
\hline & Počet schránok & 22838 & $\mathrm{ND}$ & - \\
\hline \multirow{2}{*}{$\begin{array}{l}\text { Spojené } \\
\text { král'ovstvo }\end{array}$} & $\begin{array}{l}\text { Počet automatizovaných } \\
\text { balikových schránok }\end{array}$ & 0 & 0 & 0 \\
\hline & Počet schránok & 115364 & 115247 & 115151 \\
\hline
\end{tabular}


Porovnaním tabul'ky 1 a 2 je možné vidiet', že štatistiky uvádzané v Česku a na Slovensku (uvedené vo Výročných správach) sa líšia od údajov uvádzaných v databázach UPU a to $\mathrm{v}$ uvedených počtoch automatizovaných balíkových schránok, konkrétne pre Slovensko za rok 2016 a pre Českú republiku za celé obdobie. Pod pojmom automatizované balíkové schránky je možné chápat' balíkomaty, prípadne kiosky, v závislosti od poštového operátora.

Komparáciou používaných poštových schránok (určených na podávanie listových zásielok) vo vybraných krajinách (Slovensko, Česko, Pol'sko, Spojené král'ovstvo) je možné tvrdit', že všetky majú podobné atribúty, či už sa jedná o spôsob vhadzovania listových zásielok alebo spôsob vyberania zásielok z uvedených schránok povereným zamestnancom príslušného poštového podniku. Pri poštových schránkach je d’alej zachovaná aj uniformita farebnosti poštových schránok v rámci prevádzky poštovým podnikom: Pol'ská pošta má schránky zafarbené na červeno, Slovenská a Česká pošta v odtieňoch oranžovej a Royal Mail vo farbách červenej a modrej. Uvedené podniky majú označenia poštových schránok informačnými štítkami, na ktorých sú uvedené dni v týždni a čas výberu poštovej schránky, ako aj označenie podniku jeho názvom a logom. Na schránkach sú uvádzané aj d’alšie prvky:

- Royal Mail má na schránke uvedenú aj príslušnú poštu, ktorá je poverená výberom danej schránky, telefonický kontakt aj webovú lokalitu. [19]

- Pol’ská pošta má d’alej na schránke uvedený vzor písania adresných údajov na listy. [20]

- Poštové schránky Českej a Slovenskej pošty majú v informačnom štítku uvedené aj číslo poštovej schránky, ktorá pošta zodpovedá za výber schránky a telefonický kontakt. $[8,21]$

- Navyše sú na schránke Českej pošty uvedené aj vybrané ceny poštových služieb platné ku konkrétnemu dátumu. [21]

Ani jedna z uvedených poštových schránok vybraných operátorov nedisponuje implementovaným zariadením, pracujúcim na báze informačno-komunikačných technológií. Takýmito zariadeniami však disponujú balíkomaty, ktoré bližšie v článku neboli rozoberané, ked’že ich potenciál do budúcna je značný, minimálne pre najbližšie desatročie. Uvedené poštové schránky sú jednoduché a technicky zastaralé pre podmienky 21 . storočia.

\section{Záver}

Z uvedenej analýzy vyplýva, že uvedené podniky, poverené poskytovaním univerzálnej služby, nevyužívajú na vyberanie listových zásielok poštovými schránkami schránky vybavené inteligentnými zariadeniami. Inteligentné zariadenia (pozostávajúce zo systému prepojených napr. senzorov a vysielačov) by mohli zabezpečit' komunikáciu medzi takýmto zariadením, umiestneným v poštovej schránke a poštou, poverenou výberom danej schránky v čase, kedy je poštová schránka naplnená. Takto by sa predchádzalo vyberaniu nenaplnených poštových schránok, ktoré súčasné kvalitatívne požiadavky na univerzálnu službu požadujú realizovat' proces každodenným výberom (výberom v pracovných dňoch). Niektorí zahraniční operátori však uvádzajú aj na svojich stránkach, či už prepojenie možností podávania balíkov aj listov do jednej schránky alebo implementovanie inteligentných zariadení do schránok, nie len domových listových schránok. Na výber však tieto podniky využívajú aj balíkomaty, ktoré už disponujú určitými zariadeniami (komunikujúcimi na báze informačno-komunikačných technológií), umožňujúcimi istý typ komunikácie. Preto v závislosti na súčasnom trende implementácie Industry 4.0 by bolo možné tieto schránky vybavit' takýmito inteligentnými zariadeniami (ich systémami) alebo z hl'adiska regulačných 
úradov jednotlivých krajín začat' adekvátne sledovanie takýchto poštových schránok pre ich možné vyradenie z prevádzky a nahradenie inými typmi zariadení.

\section{Pod'akovanie / Grantová podpora}

This research has been supported by the University of Zilina in the scope of Institutional research1/KS/2020 „Business Intelligence as a tool to support managers' decisions" and Project CIS by Ministry of Educations SR.

\section{Literatúra}

[1] Post office self service kiosk. [online]. [cit. 5.10.2020]. Dostupné na internete: $<\mathrm{http}$ ://www.kiosk.medinyx.com/post-office-self-service-kiosk.html $>$.

[2] Die neuen SB Zonen: 24/7 geöffnet!. [online]. [cit. 5.10.2020]. Dostupné na internete: $<\mathrm{https}: / /$ www.youtube.com/watch?reload=9\&reload=9\&v=7vI_JZg_-nY $>$.

[3] Automated lockers and self-service kiosks rule as Post Office hits digital age. [online]. [cit. 5.10.2020]. Dostupné na internete: $<$ https://www.theguardian.com/business/2014/sep/07/post-office-digital-automationonline-shopping $>$.

[4] TP I-1 Listové a balíkové zásielky, 3. čast' Podávanie, 1. 6. 2019'INT' ako Príloha k opatreniu č. 232 PV SP, čiastka 17/2017 s platnou účinnost’ou od 1. 10. 2017 (Vypracoval: odbor technológie produktov a procesov). [cit. 5.10.2020]

[5] Ray/First \& Last Mile. [online]. [cit. 5.10.2020]. Dostupné na internete: $<\mathrm{http}: / /$ www.welltechq.com/portfolio-item/mailparcel-kiosk/ $>$.

[6] HUDÁK, M. Čo je to Near Field Communication - NFC?. 2017. [online]. Techbox. [cit. 5.10.2020]. Dostupné na internete: $<$ https://techbox.dennikn.sk/temy/co-je-to-nfc/ $>$.

[7] RAY ENG. [online]. [cit. 5.10.2020]. Dostupné na internete: $<$ https://www.youtube.com/embed/p0AybtSV7I8>.

[8] KONCOVÁ, D.: Inteligentná poštová schránka ako kontaktné miesto poštovej siete. Diplomová práca. Žilina: EDIS, 2020, 78 s.

[9] Požiadavky na kvalitu univerzálnej služby. [online]. [cit. 6.10.2020]. Dostupné na internete: <https://www.posta.sk/subory/561/poziadavky-na-kvalitu-2009.pdf>.

[10]Zákon o poštových službách a o zmene a doplneni niektorých zákonov 324/2011 Z.z.. [online]. [cit. 6.10.2020]. Dostupné na internete: <https://www.epi.sk/zz/2011-324>.

[11]Zákon o poštovních službách a o změně některých zákonů (zákon o poštovních službách) c. 29/2000 Sb.. [online]. [cit. 6.10.2020]. Dostupné na internete: $<$ https://www.zakonyprolidi.cz/cs/2000-29>.

[12] Vestnik zákonov Pol’skej republiky o podmienkach poskytovania univerzálnych služieb určeným poštovým podnikom. [online]. [cit. 8.10.2020]. Dostupné na internete: $<$ http://isap.sejm.gov.pl/isap.nsf/download.xsp/WDU20130000545/O/D20130545.pdf $>$.

[13]Postal Services Act 2011. [online]. [cit. 9.10.2020]. Dostupné na internete: $<$ https://www.legislation.gov.uk/ukpga/2011/5/section/31>.

[14]Informace o výsledcich poskytováni a zajištováni základnich služeb a vyhodnocení parametrů kvality za rok 2019. [online]. [cit. 9.10.2020]. Dostupné na internete: $<$ https://www.ceskaposta.cz/documents/10180/6119731/informace-prospotrebitele+\%281\%29.pdf/5e5a151a-ccc2-0275-7cbe-808b80c9f4ec $>$.

[15] Seznam poštovních schránek. [online]. [cit. 9.10.2020]. Dostupné na internete v časti Zákaznícke výstupy ako zazipovaný súbor .xls: <https://www.ceskaposta.cz/kestazeni/zakaznicke-vystupy\#1>.

[16]Poštové zvesti Slovenskej pošty, a.S.. [online]. [cit. 9.10.2020]. Dostupné na internete: $<$ https://www.posta.sk/subory/40146/postove-zvesti-zima-20192020.pdf >. 
[17] Vybrané štatistiky poštových služieb dostupné na UPU [online]. [cit. 9.10.2020]. Dostupné na internete: $<$ http://pls.upu.int/pls/ap/ssp_report.CreateReport2020>.

[18] Manažérske informačné systémy / Iveta Kremeňová, Juraj Fabuš, Martina Kováčiková. 1. vyd. - Bratislava : DOLIS, 2015. - 201 s., [AH 13,32] : obr., tab. - ISBN 978-80-8181021-3.

[19]Businessman Sending Mail on one of the London Streets stock photo. [online]. [cit. 15.10.2020]. Dostupné na internete: <https://www.istockphoto.com/photo/businessmansending-mail-on-one-of-the-london-streets-gm458093871-

16922556?utm_source=pixabay\&utm_medium $=$ affiliate\&utm_campaign=SRP_photo_sp onsored\&utm_term $=$ post + box + royal + mail $>$.

[20]Poczta posta mailbox. [online]. [cit. 15.10.2020]. Dostupné na internete: $<$ https://commons.wikimedia.org/wiki/File:Poczta_Polska_Mailbox.jpg>.

[21]PRESSLER, G. Post Boxes of the World: Škatule. [online]. [cit. 15.10.2020]. Dostupné na internete: $<$ https://sk.pinterest.com/pin/167829523583745060/>. 